Marek Jasiński

Niepaństwowa Wyższa Szkoła Pedagogiczna w Białymstoku

\title{
Człowiek poznający samego siebie według koncepcji Seligmana (style wyjaśniania a wyuczona bezradność)
}

\section{SELIGMAN'S CONCEPT OF MAN'S CONSCIOUSNESS OF HIMSELF (STYLES OF EXPLAINING VS. LEARNED HELPLESSNESS)}

The article presents the concept of explanation styles and the theory of learned helplessness developed by cognitive psychologist Martin Seligman. His idea is very fruitful from the cognitive point of view, and, at the same time, it can be used in clinical practice. The author of the article presents Seligman's theory with particular regard to the impact of a selected attribution style and learned helplessness on intrapsychological and interpersonal functioning of a human being. He has also highlighted deliberate application of a given style in order to avoid destructive effects. The author illustrates the concept under discussion with examples. The article also presents fundamental attribution errors and disfunctional beliefs that affect the correct assessment of the phenomena and, consequently, the emergence of errors in thinking and in attitudes towards the surrounding reality.

Key words: Martin Seligman, styles of explaining, attribution styles, learned helplessness, cognitive psychology, disfunctional beliefs, generalization, personalization, depression.

Koncepcja psychologa poznawczego Martina Seligmana odwołuje się do dwóch rodzajów zjawisk: wewnętrznych procesów umysłowych oraz procesów uczenia się, które w oparciu o doświadczenia jednostki tworzą względnie trwałe schematy myślenia i zachowania. Dla zrozumienia tej koncepcji trzeba wprowadzić dwa pojęcia: wyuczonej bezradności i stylu wyjaśniania. Będą one dokładniej omówione w dalszej części 
tekstu. Wyuczona bezradność to stan, w jaki popada jednostka poddana ciągłym niepowodzeniom ze strony zewnętrznych okoliczności, na które nie może w żaden sposób wpłynąć. Uczy się więc w pewien sposób bezradności i pasywności jako stałego elementu zachowania i myślenia w sytuacjach trudnych. Eksperymenty przeprowadzone przez Seligmana doprowadziły go do wniosku, że poddanie jednostki oddziaływaniu przykrych bodźców i jednocześnie pozbawienie jej możliwości wpływu na tę sytuację wywołuje u niej specyficzny stan bezradności. Na podstawie wywiadów z badanymi osobami oraz obserwacji ich zachowania się w trakcie eksperymentów określił on właściwe symptomy:

- obniżenie nastroju, negatywna samoocena, oskarżanie się za niepowodzenia;

- rezygnacja, utrata motywacji do działania, bierność;

- spowolnienie reakcji motorycznych;

- trudności w koncentracji, deficyty w zakresie uczenia się i myślenia.

Atrybucja w rozumieniu autora oznacza wyjaśnianie przyczyn wydarzeń. Stała dyspozycja jednostki do dokonywania jednego typu atrybucji określana jest jako styl atrybucyjny. Umiejętność poprawnego zdefiniowania tego stylu pozwala na jego ewentualną modyfikację w przypadku, gdy niesie on ze sobą niekorzystne skutki w postaci obniżenia samooceny, prowokowania dalszych niekorzystnych zdarzeń itp. Autor w książce Optymizmu można się nauczyć ${ }^{1}$, definiuje styl wyjaśniania jako pewien sposób myślenia, nawyk wykształcony w dzieciństwie i okresie dojrzewania. Styl wyjaśniania lub inaczej atrybucyjny wywodzi się wprost z opinii, jaką dany człowiek ma na swój temat i o swoim miejscu w świecie i zależy bezpośrednio od tego, czy uważa się za kogoś wartościowego i na wiele zasługującego, czy też za kogoś bezwartościowego. Styl wyjaśniania decyduje o tym, czy ktoś stanie się bardziej optymistyczny w spostrzeganiu rzeczywistości i zdarzeń czy też bardziej pesymistyczny. To z kolei w znaczący sposób wpływa m.in. na efektywność jego pracy i jakość interakcji międzyludzkich.

Omawiając cechy stylów wyjaśniania czy też atrybucji prześledzimy jak określony styl może wpływać na skuteczność pracy człowieka, jak to ewentualnie oddziaływuje na innych ludzi, z którymi wchodzimy $\mathrm{w}$ interakcje społeczne. Który z tych stylów należałoby wzmacniać, a który eliminować. Zastanowimy się też nad pozytywnym i negatywnym obliczem tych stylów.

Styl wyjaśniania, według Seligmana, ma trzy istotne wymiary: stałość, zasięg i personalizacja.

M. Seligman, Optymizmu można się nauczyć, Poznań 2002. 


\section{Stałość}

Ludzie, którzy łatwo poddają się rezygnacji, uważają, że ich niepowodzenia mają trwały, stały charakter, że będą ich spotykać przez całe życie. Natomiast osoby, które nie poddają się i nie zachowują bezradnie, pasywnie są przekonani, że przyczyny ich niepowodzeń są chwilowe, przejściowe. Oto przykłady wypowiedzi osób z tych dwóch kategorii oceny sytuacji. Osoba, która uznaje stały charakter niepowodzeń powie: „w ogóle nie potrafię skutecznie wpłynąć na zachowanie mojego partnera i już nigdy nie będę w stanie tego zrobić"; osoba, która uznaje chwilowy charakter niepowodzeń powie: „ostatnio nie wiedzie mi się w przekonywaniu partnera do swoich racji. Muszę poczekać na bardziej pomyślny rozwój wydarzeń i wtedy powinno mi się to udać". Zatem osoba ze stylem pesymistycznym będzie stosowała predykatory typu: zawsze, nigdy, każdy itp., osoba preferująca styl optymistyczny będzie opisywać niepowodzenia słowami: czasami, ostatnio, w tym momencie itp. Wymiar „stałość” decyduje o tym, jak długo jednostka poddaje się rezygnacji. Wyjaśnianie niepowodzeń poprzez doszukiwanie się ich trwałych przyczyn prowadzi do długotrwałej bezradności, natomiast wyjaśnianie ich za pomocą przyczyn krótkotrwałych uodparnia na bezradność. Trudno oczekiwać skutecznej interakcji w relacji partnerskiej, kto będzie wewnętrznie przekonany, że nigdy nie uda mu się wpłynąć zgodnie ze swoją wolą na drugą osobę, niezależnie od swoich rzeczywistych możliwości. Osoba, który dostrzega przejściowe przyczyny swoich niepowodzeń, w stosunkowo krótkim czasie będzie w stanie podjąc ,skuteczną" interakcję.

Optymistyczny styl wyjaśniania pomyślnych wydarzeń jest dokładnym przeciwieństwem optymistycznego stylu wyjaśniania wydarzeń niepomyślnych. Ci, którzy uważają, że pomyślne wydarzenia mają przyczyny o stałym charakterze są większymi optymistami niż ci, którzy sądzą, że przyczyny te mają charakter krótkotrwały. Osoba ze stylem optymistycznym powie: „zawsze dopisuje mi szczęście”; osoba ze stylem pesymistycznym powie: „to mój szczęśliwy dzień i ciężko na niego zapracowałem". Innymi słowy, optymiści wyjaśniając sobie przyczyny pomyślnych wydarzeń skłonni są traktować je jako czynniki stałe, doszukują się ich więc w trwałych cechach, które działają przez cały czas. Pesymiści upatrują przyczyn pozytywnych osiągnięć w czynnikach przejściowych, takich jak: nastrój, duży wysiłek włożony w realizację zamierzeń i uważają, że te dobre chwile przychodzą tylko czasami, że jest to zrządzenie losu. W tym przypadku postawa optymistycznie nastawionego człowieka może mieć dwa oblicza; z jednej strony koncentrowanie się na swoich mocnych stronach i uważanie ich 
za wartości trwałe, może wpłynąć pozytywnie na wiarę w skuteczność swoich oddziaływań, z drugiej strony taka postawa blisko powiązana byłaby z brakiem samokrytycyzmu, z przecenianiem swoich możliwości. Można wtedy nie dostrzec np. zagrożenia, bezgranicznie ufając w swoje szczęście i powodzenie, narażając przez to siebie i ewentualnie drugą osobę. Optymista może bagatelizować, bądź nie dostrzegać trudności i przez to może być narażony na dodatkowe, nieprzewidziane konsekwencje. Pesymiście trudno jest się cieszyć z życia, bo on z kolei nie przypisuje należytej wagi do wydarzeń pomyślnych, a skupia się na wydarzeniach niepomyślnych. Postawa optymisty jest więc bardziej „ryzykowna”, ale pozwala na odczuwanie całej palety uczuć, nie tylko pozytywnych, u pesymisty jest bezpiecznie, ale za to dostęp do uczuć pozytywnych jest znacznie ograniczony, może ukształtować się postawa anhedonii.

Te stwierdzenia są istotne dla zrozumienia mechanizmów motywacyjnych ludzkiego działania. Optymiści przyciągają w pewien sposób kolejne pomyślne wydarzenia, ponieważ dopatrują się w sukcesie trwałych, wewnętrznych przyczyn, natomiast pesymiści mają szanse na gromadzenie kolejnych negatywnych doświadczeń, ponieważ bagatelizują ewentualne osiągnięcia, traktując je jako szczęśliwe zrządzenie losu, przypadkowy traf, w którym oni nie mają swojego udziału. Widać zatem, że działa tu mechanizm błędnego koła; przyjęcie określonego stylu wyjaśniania i konsekwentne jego utrzymywanie utrwala daną strategię i dostarcza argumentów na jej utrzymywanie. Utrzymanie z kolei takiego stylu prowadzi do „przywoływania” określonych zdarzeń i koło się zamyka.

Martin Seligman w polecanej już książce Optymizmu można się nauczyć, a także w pozycji Petnia życia ${ }^{2}$ tłumaczy ten wymiar stylu wyjaśniania (zasięg) jako sposób przeżywania niepowodzeń w ograniczonym bądź uniwersalnym zakresie. Ci, którzy tłumaczą sobie własne niepowodzenia zjawiskami o zasięgu uniwersalnym, przeżywając niepowodzenie w jednej dziedzinie życia, poddają się również we wszystkich pozostałych. Natomiast osoby, które przypisują swe niepowodzenia działaniu przyczyn o ograniczonym zasięgu, mogą odczuć bezradność w tej dziedzinie życia, w której spotkało ich niepowodzenie, ale nie wpływa to destrukcyjnie na realizację celów w innych sektorach życia.

Wyjaśnienia o zasięgu uniwersalnym powodują bezradność w wielu różnych sytuacjach, natomiast wyjaśnienia o zasięgu ograniczonym jedynie w sferze, w której doszło do porażki. Optymista uważa, że

M. Seligman, Petnia życia, Poznań 2011. 
niepomyślne wydarzenia mają przyczyny o ograniczonym zasięgu, natomiast wydarzenia pomyślne wpływają korzystnie na jego wszel- Nauka kie poczynania. U pesymisty myślenie jest odmienne: wydarzenia niepomyślne mają przyczyny o zasięgu uniwersalnym, a więc ulegają generalizacji, a pomyślne powodowane są przez czynniki o zasięgu ograniczonym. Przykładami tych dwóch stylów wyjaśniania mogą być następujące wypowiedzi: styl pesymistyczny (zasięg ograniczony) „jestem bystry tylko w naukach ścisłych”; styl optymistyczny (zasięg uniwersalny) - ,jestem bystry”.

Ten wymiar stylu wyjaśniania jest bardzo istotny. Pesymista generalizuje każde niepowodzenie, przez co zniechęca się do podejmowania jakiegokolwiek działania. Optymista natomiast ma wszelkie podstawy do aktywizacji działania, ponieważ odczuwając dotkliwie niepowodzenie w określonej sferze życia, nie przenosi tego na pozostałe sfery.

Według Seligmana, odkrywanie krótkotrwałych, o ograniczonym zasięgu przyczyn niepowodzeń jest sztuką znajdywania nadziei. Krótkotrwałe przyczyny ograniczają bezradność w czasie, przyczyny o ograniczonym zasięgu redukują jej zakres do sytuacji, w której doznano niepowodzenia. Znajdywanie natomiast trwałych, o uniwersalnym zasięgu, przyczyn niepowodzeń odbiera wszelką nadzieję. Przykłady wypowiedzi ilustrujących omawiane zjawisko mogą być następujące: wyjaśnienia dające nadzieję - „ten guz to na pewno nic groźnego”, „moja partnerka była w złym nastroju”, a w wyjaśnieniach odbierających nadzieję - „ten guz to na pewno rak”, „wszystkie kobiety są nie do wytrzymania".

\section{Personalizacja wewnętrzna i zewnętrzna}

Ostatnim wymiarem stylu wyjaśniania jest personalizacja. W przypadku niepomyślnych wydarzeń można obwiniać za to siebie (personalizacja wewnętrzna) lub innych (personalizacja zewnętrzna). Obwinianie za niepowodzenia siebie powoduje w konsekwencji niskie mniemanie o sobie. Ci, którzy winę składają na czynniki zewnętrzne, nie tracą dobrego mniemania na swój temat. A oto przykłady obu rodzajów personalizacji: „nie mam uzdolnień do zawodu, który wykonuję” versus „nie mam szczęścia w tym zawodzie”. Personalizacja wewnętrzna jak i zewnętrzna przedstawiają zaburzoną perspektywę, bowiem niepowodzenia, jakie się nam przytrafiają wynikają zarówno z nas samych jak i okoliczności zewnętrznych.

Ludzie, którzy uważają, iż to oni sami sprawiają, że wydarzenia przybierają pomyślny obrót, podobają się sobie bardziej niż ci, którzy 
skłonni są przypisywać pomyślne wydarzenia działaniu innych ludzi lub okoliczności.

$\mathrm{Z}$ tego co do tej pory zaprezentowano można wywnioskować, że należałoby umacniać optymistyczny styl wyjaśniania, tym bardziej, że taka postawa może być „zaraźliwa” dla innych i pozytywnie wpływać na ich siły odpornościowe i dobrą kondycję psychofizyczną.

To, co utrudnia zastosowanie optymistycznego stylu wyjaśniania, a także bardziej realistycznej oceny rzeczywistości i własnych możliwości są różnego rodzaju błędy logiczne i zniekształcenia poznawcze. Ich eliminacja albo większa kontrola nad nimi pozwala na zastosowanie bardziej adekwatnego stylu wyjaśniania zdarzeń, a przez to większą skuteczność oddziaływania. Błędy te i zniekształcenia powstają najczęściej w domu rodzinnym i są utrwalonymi schematami radzenia sobie w sytuacjach trudnych, co często jest drogą na skróty. Typowe błędy są następujące: arbitralne wnioskowanie:

- jest to przyjmowanie postawy arbitra, nieomylnego sędziego; taka osoba nie liczy się z faktami czy rzeczywistością; jest przekonana o swojej nieomylności i prawdziwości stwierdzeń, stąd też jest zupełnie niepodatna na wszelkie sugestie czy inne argumenty; selektywne abstrahowanie:

- polega na grupowaniu niektórych szczegółów, koncentracji na nich i na ich podstawie formułowanie ogólnego wniosku dotyczącego życia, ludzi i samego siebie; w ten sposób ignorowane są niekiedy ważniejsze, istotniejsze elementy sytuacji i wtedy nasz osąd jest nieprawdziwy;

nadmierna generalizacja:

- jest to przekonanie, że pojedyncze zdarzenia będą się nieustannie powtarzać w przyszłości; coś co nastąpiło dziś, będzie miało tendencję do ustawicznego odnawiania się w przyszłości; jest to nieuprawomocnione przekonanie nadające bieżącemu wydarzeniu status trwałości i powtarzalności;

wyolbrzymienie i minimalizowanie:

- jest to błędna ocena ważności i wielkości; występuje tendencja do niedoceniania lub przeceniania własnych pozytywnych stron oraz błędów lub niepowodzeń;

personalizacja:

- jest to nadmierna koncentracja na sobie z jednoczesną gloryfikacją swoich wpływów i znaczenia dla przebiegu zdarzeń;

absolutystyczne, dychotomiczne myślenie:

- opisując siebie, osoba stosuje ekstremalne kategorie dobra i zła, bez stanów pośrednich, „wszystko albo nic”, „teraz albo 
nigdy"3; taka ocena siebie jest $\mathrm{z}$ tej perspektywy nierzetelna i nierzeczywista.

Oto inne, bardziej konkretne przykłady dysfunkcyjnych przekonań:

- skupianie się na negatywnych aspektach sytuacji, a pomijanie pozytywnych;

- automatyczne deprecjonowanie pozytywnych informacji;

- wyolbrzymianie niedoskonałości i umniejszanie pozytywnych cech;

- opieranie się na emocjach jako dowodzie na prawdziwość;

- stosowanie nieadekwatnych określeń sytuacji, negatywne określenie powoduje reakcję emocjonalną negatywną;

- wnioskowanie na podstawie nieistotnych faktów;

- myślenie zdominowane przez powinności i nakazy.

Kolejną istotną koncepcją Seligmana, która należy już do kanonów psychologii jest teoria wyuczonej bezradności. Badania, które przeprowadził wykazały, że zanim dojdzie do pełnego zaburzenia depresyjnego, najpierw u ludzi pojawia się wyuczona bezradność. Ustawiczne doświadczanie bezradności przy pokonywaniu wszelkich trudności jest najprostszą drogą do powstawania zaburzeń depresyjnych. Kluczowym elementem w powstawaniu wyuczonej bezradności jest sposób, w jaki jednostka interpretuje przyczyny spotykających ją niepowodzeń, na które dana osoba uważa, że nie ma żadnego wpływu Martin Seligman uważa, że zmieniając styl wyjaśniania zdarzeń (porażek) z pesymistycznego na optymistyczny, powoduje się usunięcie objawów wyuczonej bezradności, a tym samym nie dopuszcza się do rozwinięcia pełnego zaburzenia depresyjnego. Optymizm może wpływać na dobry stan zdrowia na cztery sposoby:

1. Styl wyjaśniania jest wielkim modulatorem wyuczonej bezradności. Optymiści nie poddają się bezradności. Taka osoba ma w ciągu życia mniej okresów wyuczonej bezradności niż osoba o nastawieniu pesymistycznym, a im mniej takich okresów w tym lepszym stanie powinien być system immunologiczny. Innymi słowy, pierwszy sposób, w jaki optymizm może wpływać na stan zdrowia polega na zapobieganiu bezradności, a przez to na wzmacnianiu systemu immunologicznego.

2. Drugi sposób dobroczynnego wpływu optymizmu na zdrowie polega na przestrzeganiu zdrowego trybu życia i zasięganiu porad lekarskich. Pesymista, który uważa, że choroba jest stała, ma zasięg uniwersalny i przyczynę wewnętrzną stwierdzi: „nic co

M. Huflejt-Łukasik, Poznawczo-behawioralna psychoterapia depresji, [w:] L. Grzesiuk (red.), Psychoterapia, Warszawa 1994, s. 339-416. 
robię nie ma na to żadnego wpływu, więc po co robić cokolwiek". Jest mało prawdopodobne, by taka osoba zrobiła cokolwiek dla poprawy stanu zdrowia.

3. Trzeci sposób dotyczy liczby niepomyślnych wydarzeń przytrafiających się danej osobie. Udowodniono, że im więcej niepomyślnych wydarzeń spotyka osobę w danej chwili, tym częściej ona choruje. Pesymiści są bardziej bierni, a zatem mniej skłonni do tego, by podjąć kroki, które miałyby zapobiec niepomyślnym wydarzeniom, a także położyć im kres jak się pojawią.

4. Ostatnia przyczyna, z powodu której optymiści powinni się cieszyć lepszym zdrowiem niż pesymiści dotyczy oparcia w innych osobach. Zdolność utrzymywania głębokich przyjaźni i zdolność kochania innych zdaje się mieć istotne znaczenie dla zdrowia fizycznego. Osoby stanu wolnego są bardziej narażone na depresję niż osoby żyjące w związku małżeńskim. Pesymiści nie szukają oparcia w innych ludziach. Optymistyczny styl wyjaśniania pozwala przetrwać znacznie dłużej w zdrowiu, zwłaszcza wtedy gdy choroba nie poczyniła jeszcze zbytniego spustoszenia w organizmie.

Wnioski płynące z koncepcji Seligmana wydają się być jednoznaczne: należy wzmacniać i promować u ludzi optymistyczny styl wyjaśniania. Służy on zarówno utrwaleniu ,potencji psychicznej”, wpływa też pozytywnie na interakcje z innymi ludźmi. Człowiek stosując optymistyczny styl wyjaśniania stwarza sobie dogodniejsze warunki do poprawy stanu zdrowia, poprzez wzmocnienie systemu immunologicznego, jak też w pewien sposób zabezpiecza się przed wystąpieniem rozlicznych schorzeń psychosomatycznych. Postawa innych osób stosujących optymistyczny styl wyjaśniania sprzyja rozbudzeniu nadziei na wyleczenie i przez to aktywizuje jego siły odpornościowe. Korzyści ze stosowania optymistycznego stylu wyjaśniania jest znacznie więcej i nie dotyczą one tylko poprawy stanu zdrowia i ogólnie kondycji psychofizycznej, ale poprawiają samoocenę i mobilizują do realizacji planów życiowych. Należy jednak pamiętać, że optymistyczny styl wyjaśniania nie może być utożsamiany z postawą nonszalancji, nieuzasadnionej pewności siebie czy brakiem samokrytycyzmu. Taka postawa rodziłaby liczne zagrożenia i nie sprzyjała rozwojowi wewnętrznemu.

Słowa kluczowe: Martin Seligman, style wyjaśniania, style atrybucji, wyuczona bezradność, psychologia poznawcza, dysfunkcyjne przekonania, generalizacja, personalizacja, depresja. 